\title{
Fatty acids as tracers of organic matter in the sediment and food web of a mangrove/intertidal flat ecosystem, Okinawa, Japan
}

\author{
Tarik Meziane*, Makoto Tsuchiya \\ Laboratory of Ecology and Systematics, University of the Ryukyus, Senbaru 1, Nishihara, Okinawa, 903-0213, Japan
}

\begin{abstract}
Surface sediments and marine invertebrates, collected from 2 intertidal flats on Okinawa Island, 1 adjacent to a mangrove system, were analysed for fatty acid composition. The detection of fatty acid markers found in mangrove leaves in the organic matter of the surface sediments, coupled with measurements of $\mathrm{C}: \mathrm{N}$ ratios, showed that organic matter from the mangrove forest (in Oura Bay) is exported to the intertidal flat in both the rainy season and the dry season. This export seems to be higher in the rainy season. However, bacteria, diatoms and macroalgae were the main food source in the surface sediments, as shown by the contribution of their respective fatty acid markers. These markers were also detected in the tissues of the dominant macrozoobenthic species, fiddler crabs and gastropods. Bacteria and green macroalgae were the primary food sources ingested at both sites, irrespective of season. The organic matter derived from mangroves was also ingested by the macrozoobenthos of Oura Bay, while markers of higher plants were not found in the tissues of invertebrate species at Itoman intertidal flat, the site that was not adjacent to a mangrove system.
\end{abstract}

KEY WORDS: Okinawa Island · Rainy season - Dry season · Mangrove $\cdot$ Intertidal flat $\cdot$ Fatty acid markers $\cdot \mathrm{C}: \mathrm{N}$ ratio $\cdot$ Organic matter $\cdot$ Sediment $\cdot$ Food web

\section{INTRODUCTION}

Mangrove forests, predominant in estuarine ecosystems of tropical and subtropical regions, are characterised by high primary production. The material produced, mainly leaves, enriches the bottom litter (Fleming et al. 1990). The decompostion rate of the litter and the quality of the resulting particulate organic matter and nutrients may depend on which mangrove species the leaves come from (Tam et al. 1990), on biotic factors such as bacterial activity (Bano et al. 1997). and on edaphic effects such as tidal range and temperature (Slim et al. 1997).

Litter production is exported to the intertidal flat (Woodroffe 1985). However, Robertson (1986) assumed that the export is certainly over-estimated by not considering the leaf removal by crabs in the forest. When exported, the litter material is recycled through the detritus-based food web. The effect of mangrove detri-

•E-mail: h983001@sci.u-ryukyu.ac.jp tus on intertidal secondary production is still not well understood and its effect is not always positive. Indeed, Alongi \& Christoffersen (1992) have shown that the deposition of mangrove detritus may decrease the density of the macrozoobenthos and diversity of nematodes. Moreover, Wafar et al. (1997) suggested that the energy flux from mangroves is more important for sustaining the microbial food chain and nutrient regeneration than the particulate food chain directly.

Mangrove forests in Okinawa (in the southern part of Japan) colonise some river estuaries in the northern part of the island. The litter production here is particularly elevated during the rainy and dry seasons (spring and summer, respectively; Mokolensang \& Tokuyama 1998). However, the export of litter from the mangroves to the intertidal flat and its integration into the intertidal food web remain uninvestigated. Macrobenthos was investigated in another study, unique for a mangrove/non-vegetated mudflat ecosystem, which showed high diversity and elevated densities and biomasses of benthic macrofauna (Motonaga 1977). 
The last decade has seen an increase of studies using fatty acids as markers in order to identify the origin of organic matter in coastal environments (Le Blanc et al. 1989. Canual et al. 1995, Mudge \& Gwyn Lintern 1999). Furthermore, because marine invertebrates are unable to synthesise some essential fatty acids, which are available specifically in some organic sources, the profile of fatty acid composition in their tissues can also reveal the origin of the food source(s) (Hopkins et al. 1993, Kharlamenko et al. 1995, Meziane et al. 1997). Among these fatty acids markers, the odd-branched fatty acids $15: 0$ and 17:0, iso and anteiso, and 18:1 107 are commonly considered as being predominantly synthesised by bacterial communities (Jeffries 1972, Volkman et al. 1980) and they have been used as markers of bacteria in sediments (Currie \& Johns 1988, Rajendran et al. 1992, 1993) and marine invertebrates (Kharlamenko et al. 1995, Pranal et al. 1996, Meziane et al. 1997). In the polyunsaturated fatty acids (PUFAs), the acid 20:5 33 has been strongly detected in diatoms (Pond et al. 1998), and has been used as a diatom marker in marine environments (Volkman et al. 1980, Currie \& Johns 1988, Canual et al. 1995) and in the diet of invertebrates (Kharlamenko et al. 1995, Meziane et

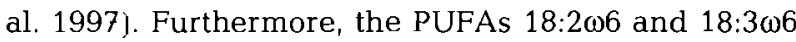
were used as markers of macroalgae (Kharlamenko et al. 1995). The long chain fatty acids (LCFAs from 26:0 to 30:0), exclusively synthesised by vascular plants (Volkman et al. 1980), have been used as tracers of these vegetal species in sediments and in animal tissues (Le Blanc et al. 1989, Rajendran et al. 1992, Meziane et al. 1997).

By examining fatty acid profiles in plants, sediments and marine invertebrates, this study aimed to assess the export of mangrove detritus to the intertidal flat and to determine its integration into the intertidal food web through the dominant species of macrozoobenthos. The investigations were made during the rainy and dry seasons on Okinawa lsland. The work was supplemented by a similar investigation at a control site that supported no mangrove forest nearby.

\section{MATERIAL AND METHODS}

Study site. Okinawa is a semi-tropical island located in the southern part of Japan (26.5 $\mathrm{N}, 128^{\circ} \mathrm{E}$; Fig. 1). The study site of Oura Bay (Fig. 1) is situated in the northern part of the island, which is characterised by laurel forests and a coastal mangrove area. This mangrove, a mixed vegetation consisting of Rhizophora stylosa, Kandelia candel, and Bruguiera gymnorhiza, colonises the mouth of the estuary where the Oura River runs into the bay. The reference site, Itoman intertidal flat, is situated in the southern part of the

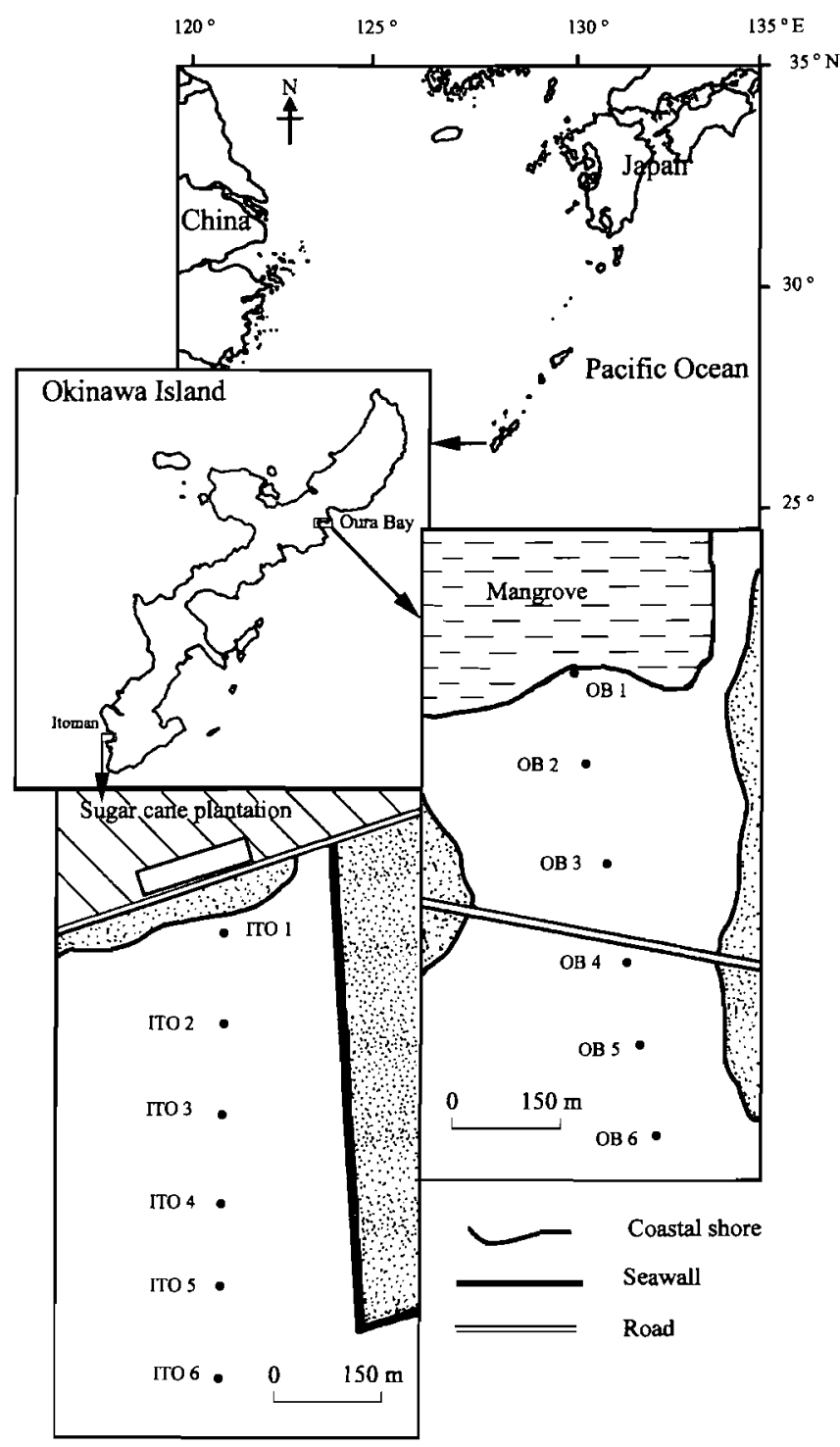

Fig. 1. Locations of Okinawa Island and the transects of sampling sites (Oura Bay and Itoman)

island (Fig. 1). The mudflat is situated against a backdrop of sugar cane plantations. Sediments are mostly muddy in Oura Bay and mostly sandy in Itoman.

Sample collection. All sediment and macrozoobenthos samples were collected on 2 separate occasions along a transect, perpendicular to the shore, at each site. The first sampling was in early May, which is the mid-period of the rainy season, and the second sampling was in the middle of summer (late July), which corresponds to a dry season of 1 mo duration. In addition, during the rainy season, fresh fallen leaves of $R$ hizophora stylosa were sampled in Oura Bay's mangrove, while thalli of the most abundant algae at both sites, Enteromorpha intestinalis and Ulva pertusa, were collected at the ltoman flat. Samples of surface sediment 
were collected by scraping the top 1 to $2 \mathrm{~cm}$ at both sites ( 6 stations eachi Fig. 1). In Oura Bay, the sampled species were the crab Uca lactea (collected at Stn OB 2), and the gastropods Terebralia sulcata ( $S \operatorname{tn} \mathrm{OB} 1$ ) and Cerithideopsilla cingulata (Stn OB 3). At the Itoman intertidal flat, the sampled species were the crabs $U$. lactea (Stn ITO 1) and Uca vocans (Stn ITO 2), and the gastropod Batillaria zonalis (Stn ITO 3). The collected invertebrates were immediately isolated, frozen $\left(-20^{\circ} \mathrm{C}\right)$ and stored for analysis. The macrozoobenthos species investigated are the dominant species at both sites (Motonaga 1977, authors' unpubl, data).

Analysis. The $C$ and $N$ content of the sediment samples were measured in a Shimadzu high sensitivity $\mathrm{N}$, $\mathrm{C}$-analyser model NC80. Two replicates were measured for each station.

For lipid extraction, $10 \mathrm{~g}$ wet weight of flora, $2 \mathrm{~g}$ dry weight (dw) of sediments and between 200 and $260 \mathrm{mg}$ $\mathrm{dw}$ of animal tissues were used following a slightly modified version of the method of Bligh \& Dyer (1959). For the animals, 10 (crabs) or 20 (gastropods) individuals were used for preparing the dry tissue pool. Lipids were extracted ultrasonically for $20 \mathrm{~min}$ with a mixture of distilled water:methanol:chloroform $\left(1: 2: 1,20 \mathrm{~cm}^{3}\right.$, $\mathrm{v}: \mathrm{v}: \mathrm{v})$. Addition of distilled water:chloroform mixture $\left(5: 5 \mathrm{~cm}^{3} \mathrm{v}: \mathrm{v}\right)$ formed an aqueous-organic 2-layer system. Lipids were transferred into the lower chloroform phase and the transfer improved by centrifugation $(2000 \mathrm{rpm}[650 \times g], 5 \mathrm{~min})$. The aqueous phase was re-extracted one more time. The separated chloroform layers were combined, rotary evaporated, and then dried under nitrogen. The extracts were saponified under reflux $\left(2 \mathrm{~h}, 100^{\circ} \mathrm{C}\right)$ with a $2 \mathrm{~mol} \mathrm{dm}{ }^{-3} \mathrm{NaOH}$ solution in methanol and distilled water $(2: 1, \mathrm{v}: \mathrm{v})$. After acidification with ultra-pure $\mathrm{HCl}$ solution $(37.5 \%), 2 \times$ $2 \mathrm{~cm}^{3}$ of chloroform were added successively to recover the lipids. The chloroform extracts were combined, evaporated and dried under a nitrogen stream. Total lipids contained in the chloroform were transmethylated under reflux with $14 \% \mathrm{BF}_{3}$-methanol for $10 \mathrm{~min}$. After cooling, lipids were re-extracted with chloroform and washed with distilled water. After evaporation under a nitrogen stream, the extracts were weighed and redissolved in chloroform:methanol $(2: 1, \mathrm{v}: \mathrm{v})$. Separation of lipid fractions was facilitated using high-performance thin-layer chromatography (HPTLC), which was performed on plates coated with silica. The bands containing fatty acid methyl esters (FAMEs) were scraped and dissolved in a mixture of chloroform:methanol $(2: 1$; v:v) at $40^{\circ} \mathrm{C}$ for $60 \mathrm{~min}$. FAMEs were then isolated in the same solution until analysis by gas chromatography.

The samples were analysed by a GC 14.B Shimadzu gas chromatograph equipped with flame ionisation. FAMEs were separated with an FFAP-polar capillary column ( $30 \mathrm{~m} \times 0.32 \mathrm{~mm}$ internal diameter, $0.25 \mathrm{~mm}$ film thickness). Hydrogen was used as a carrier gas. After injection at $60^{\circ} \mathrm{C}$, the oven temperature was raised to $150^{\circ} \mathrm{C}$ at a rate of $40^{\circ} \mathrm{C} \mathrm{min}^{-1}$, then to $230^{\circ} \mathrm{C}$ at $3^{\circ} \mathrm{C} \mathrm{min}^{-1}$, and finally held constant for $30 \mathrm{~min}$. The flame ionisation was held at $240^{\circ} \mathrm{C}$. FAMEs were identified by comparing their retention times with those of a standard.

Fatty acids are designated as $X: Y \omega Z$, where $X$ is the no. of carbon atoms, $Y$ is the no. of double bonds and $\mathrm{Z}$ is the position of the ultimate double bond from the terminal methyl group. The analytical precision for samples was generally $<5 \%$ for total amounts and major components of FAMEs.

\section{RESULTS}

\section{Fatty acid markers in plants}

The palmetic fatty acid (16:0) was the most commonly detected compound $(43.2$ to $67.5 \%)$ in the leaves of Rhizophora stylosa and the thalli of Enteromorpha intestinalis and Ulva pertusa (Table 1). The LCFAs, markers of vascular plants (Table 2), were found only in Rhizophora stylosa leaves (5.9\% of total fatty acids; Table 1).

In Rhizophora stylosa, the contribution of the PUFAs $18: 2 \omega 6$ and $18: 3 \omega 6$ was about $7 \%$ of total fatty acids (Table 1). However, higher amounts of these fatty acids, markers of macroalgae (Table 2), were found in Enteromorpha intestinalis and Ulva pertusa $(24.7 \%$ and $12.6 \%$ respectively; Table 1 ).

\section{Surface sediments}

$\mathrm{C}: \mathrm{N}$ atomic ratio. The $\mathrm{C}: \mathrm{N}$ atomic ratio values in Oura Bay and Itoman intertidal flat, during the rainy and the dry seasons, are presented in Tables 3 \& 4. At

Table 1. Percentage levels of ubiquitous fatty acid (16:0), polyunsaturated fatty acid markers (PUFA markers) and long chain fatty acids (LCFAs) in Rhizophora stylosa leaves and thalli of Enteromorpha intestinalis and Ulva pertusa. -: not detected

\begin{tabular}{|c|c|c|c|}
\hline & $\begin{array}{c}\text { Rhyzophora } \\
\text { stylosa (leaves) }\end{array}$ & $\begin{array}{c}\text { Enteromorpha } \\
\text { intestinalis }\end{array}$ & $\begin{array}{c}\text { Ulva } \\
\text { pertusa }\end{array}$ \\
\hline $16: 0$ & 53.5 & 43.2 & 67.5 \\
\hline $\begin{array}{l}18: 2 \omega 6 \\
18: 3 \omega 6\end{array}$ & $\begin{array}{l}4.6 \\
2.0\end{array}$ & $\begin{array}{l}12.7 \\
12.0\end{array}$ & $\begin{array}{r}11.5 \\
1.0\end{array}$ \\
\hline PUFA markers & 6.6 & 24.7 & 12.6 \\
\hline $26: 0$ & 1.7 & - & - \\
\hline $28: 0$ & 3.3 & - & - \\
\hline $30: 0$ & 0.9 & - & - \\
\hline$\sum$ LCFAs & 5.9 & - & - \\
\hline
\end{tabular}


Table 2. Fatty acid markers assigned to organic sources

\begin{tabular}{|c|c|}
\hline Fatty acids (FAs) & Organisms \\
\hline $\begin{array}{l}15: 0 \text { iso, } 15: 0 \text { anteiso, } 17: 0 \text { iso, } \\
17: 0 \text { anteiso, } 18: 1 \omega 7\end{array}$ & Bacteria \\
\hline $20: 5 \omega 3$ & Diatoms \\
\hline $18: 2 \omega 6,18: 3 \omega 6$ & Green macroalgae \\
\hline $26: 0,28: 0,30: 0$ & Vascular plants \\
\hline
\end{tabular}

Oura Bay, the $\mathrm{C}: \mathrm{N}$ atomic ratio ranged from 8.2 to 286.9 during the rainy season and from 3.6 to 29.7 during the dry season. At Itoman, the $\mathrm{C}: \mathrm{N}$ ratios values were higher in the rainy season (41.0 to 83.2$)$ than in the dry season (4.7 to 5.5 ).

Fatty acid markers in surface sediments. In Oura Bay, the odd-branched fatty acids $15: 0$ and 17:0 (iso and anteiso) and 18:1 107 , markers of bacteria (Table 2), were detected (alone or together) at all stations and during both seasons (Table 3). The sum of their relative concentrations ranged from 2.9 to $7.7 \%$ in the rainy season and from 2.0 to $15.2 \%$ in the dry season. At Itoman flat, these concentrations ranged from 4.8 to $21.1 \%$ in the rainy season and from 5.8 to $12.3 \%$ in the dry season (Table 4).

In Oura Bay the acid 20:5 13 , the marker for diatoms (Table 2), was detected at only a few stations during both seasons (Stns OB 2, OB 3 and $O B$ 4). Its relative contributions ranged between 1.4 and $2.8 \%$ (Table 3 ). At Itoman, 20:5 13 was detected in the surface sediments of Stns ITO 1, ITO 3 and ITO 6 during the rainy season (Table 4). In the dry season, the diatoms marker was found at all stations, with a maximum concentration of $6.7 \%$ recorded at Stn ITO 3 (Table 4 ).

The markers of green macroalgae, the polyunsatu-

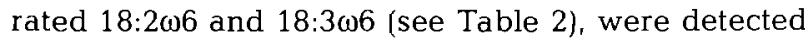
at almost all stations of Oura Bay (except Stns OB 1 and $\mathrm{OB} 6$ during the rainy season; see Table 3). A maximum value was found at Stn OB 3 during the rainy season $(22.1 \%)$. At Itoman flat, the highest contribution of these markers in the organic matter of surface sediments was found at Stn ITO 3 during the rainy season (14.4\%) (Table 4).

Vascular plant markers, the LCFAs, were detected in the surface sediments of all stations of Oura Bay during the rainy season and in 4 of them during the dry season (Table 3). However, the relative contribution of LCFAs never exceeded $3.6 \%$ (OB 2 in RS). At Itoman flat, LCFAs were not detected in the surface sediments of the intertidal flat (Table 4).

\section{Fatty acid markers in macrozoobenthos}

Bacterial markers were systematically recorded in all species at both sites (Tables 5 \& 6). In Oura Bay, relatively high percentages of these fatty acids were found in Terebralia sulcata; the values of these markers were the highest recorded $(11.4 \%$ in the rainy season and $7.1 \%$ in the dry season) compared to with other species. At Itoman flat, the relative contribution of bacterial markers in the macrozoobenthos did not vary from season to season, and comprised between 4.2 ( $U C a$ vocans: dry season) and $6.2 \%$ (U. vocans: rainy season) of the total fatty acids.

Table 3. Percentage level of 16:0, fatty acid (FA) markers of bacteria, microalgae, macroalgae and mangroves (LCFAs), and total PUFAs (including fatty acids shown in this table and those not presented) and C:N ratio of surface sediments at Stns OB1 to OB6 in Oura Bay during the rainy season (RS) and the dry season (DS). -: not detected

\begin{tabular}{|c|c|c|c|c|c|c|c|c|c|c|c|c|}
\hline & \multicolumn{2}{|c|}{ OB 1} & \multicolumn{2}{|c|}{$\mathrm{OB} 2$} & \multicolumn{2}{|c|}{ OB 3} & \multicolumn{2}{|c|}{$\mathrm{OB} 4$} & \multicolumn{2}{|c|}{ OB 5} & \multicolumn{2}{|c|}{ OB 6} \\
\hline & RS & DS & RS & DS & RS & DS & RS & DS & RS & DS & RS & DS \\
\hline $16: 0$ & 46.4 & 24.9 & 15.6 & 21.5 & 17.5 & 14.5 & 28.5 & 19.5 & 39.4 & 14.7 & 45.6 & 15.9 \\
\hline $15: 0$ iso & 2.9 & - & 1.8 & - & 2.4 & - & 0.8 & - & 1.9 & 2.3 & 7.7 & 0.8 \\
\hline $15: 0$ anteiso & - & - & 1.7 & 0.7 & - & - & - & - & 1.4 & - & - & 4.2 \\
\hline $17: 0$ iso & - & 2.5 & 0.7 & 1.2 & _- & 11.4 & 1.2 & - & 1.5 & 5.0 & - & 1.4 \\
\hline $17: 0$ anteiso & - & 3.4 & - & 2.1 & - & - & - & - & - & - & - & 2.2 \\
\hline $18: 1 \omega 7$ & - & - & 1.9 & 1.5 & 1.6 & - & 1.7 & 2.0 & 2.4 & 2.3 & - & 6.6 \\
\hline$\sum$ bacterial FA markers & 2.9 & 5.9 & 6.1 & 5.5 & 4.0 & 11.4 & 3.7 & 2.0 & 7.1 & 9.5 & 7.7 & 15.2 \\
\hline $20: 5 \omega 3$ (microalgal marker) & - & - & 3.6 & 2.1 & 2.8 & 2.8 & - & 1.4 & - & - & - & - \\
\hline $18: 2 \omega 6$ & - & 2.0 & 1.2 & 1.9 & 1.8 & 5.4 & - & 3.6 & 0.7 & 2.6 & - & 4.0 \\
\hline $18: 3 \omega 6$ & - & - & - & - & 20.3 & - & 1.1 & - & 1.2 & - & - & - \\
\hline$\sum$ macroalgal FA markers & - & 2.0 & 1.2 & 1.9 & 22.1 & 5.4 & 1.1 & 3.6 & 1.9 & 2.6 & - & 4.0 \\
\hline $26: 0$ & 2.5 & 2.0 & 3.1 & 0.8 & - & - & 0.8 & 0.9 & 2.1 & - & - & 1.1 \\
\hline $28: 0$ & - & & 0.5 & 0.7 & 3.5 & - & - & & - & - & 0.6 & \\
\hline$\sum$ LCFAs & 2.5 & 2.0 & 3.6 & 1.4 & 3.5 & - & 0.8 & 0.9 & 2.1 & - & 0.6 & 1.1 \\
\hline$\sum$ PUFAs & - & 2.3 & 5.2 & 4.0 & 43.4 & 8.6 & 1.9 & 7.2 & 2.8 & 3.1 & - & 4.6 \\
\hline $\mathrm{C}: \mathrm{N}$ & 8.2 & 12.4 & 13.5 & 3.6 & 68.4 & 5.7 & 260.7 & 5.5 & 286.9 & 14.4 & 129 & 29.7 \\
\hline
\end{tabular}


Table 4. Percentage level of 16:0, FA markers of bacteria, microalgae, macroalgae and mangroves (LCFAs), and total PUFAs and C:N ratio of surface sediments at Stns ITO1 to ITO6 in the Itoman intertidal flat during the rainy season (RS) and the dry season (DS). - not detected

\begin{tabular}{|c|c|c|c|c|c|c|c|c|c|c|c|c|}
\hline & \multicolumn{2}{|c|}{ ITO 1} & \multicolumn{2}{|c|}{ ITO 2} & \multicolumn{2}{|c|}{ ITO 3} & \multicolumn{2}{|c|}{ ITO 4} & \multicolumn{2}{|c|}{ ITO 5} & \multicolumn{2}{|c|}{ ITO 6} \\
\hline & RS & DS & $\mathrm{RS}$ & DS & RS & DS & RS & DS & RS & DS & RS & DS \\
\hline $16: 0$ & 39.0 & 38.7 & 41.3 & 44.1 & 20.5 & 21.3 & 22.5 & 35.9 & 32.8 & 21.8 & 9.1 & 32.0 \\
\hline $\begin{array}{l}\text { 15:0 iso } \\
15: 0 \text { anteiso }\end{array}$ & - & 0.7 & $\begin{array}{l}3.0 \\
1.5\end{array}$ & $\begin{array}{c}1.2 \\
-\end{array}$ & $\begin{array}{l}2.5 \\
1.6\end{array}$ & $\begin{array}{l}2.6 \\
1.4\end{array}$ & - & $\begin{array}{l}1.8 \\
1.2\end{array}$ & $\begin{array}{l}2.8 \\
1.6\end{array}$ & - & $\begin{array}{r}2.5 \\
14.8\end{array}$ & $\begin{array}{l}2.4 \\
1.2\end{array}$ \\
\hline $17: 0$ iso & 1.4 & 0.8 & 1.5 & 0.9 & 0.8 & $\begin{array}{l}1.4 \\
3.3\end{array}$ & - & 1.2 & 1.1 & 0.7 & $\begin{array}{l}14.0 \\
-\end{array}$ & 1.5 \\
\hline $17: 0$ anteiso & 0.5 & 0.5 & 0.6 & - & - & 3.0 & 3.9 & - & 1.1 & 3.1 & - & - \\
\hline $18: 1 \omega 7$ & 2.9 & 7.0 & 7.0 & 3.8 & 2.9 & 2.1 & 4.1 & 3.6 & 3.8 & 5.9 & 3.8 & 6.3 \\
\hline$\sum$ bacterial FA markers & 4.8 & 9.1 & 13.6 & 5.8 & 7.8 & 12.3 & 8.0 & 7.8 & 10.4 & 9.7 & 21.1 & 11.3 \\
\hline $20: 5 \omega 3$ (microalgal marker) & 2.2 & 1.7 & - & 5.6 & 0.8 & 6.7 & - & 2.8 & - & 3.5 & 1.9 & 2.6 \\
\hline $18: 2 \omega 6$ & 3.5 & 1.8 & 0.7 & 0.9 & - & 1.0 & - & 0.9 & 0.7 & 4.8 & 0.9 & 2.0 \\
\hline $18: 3 \omega 6$ & 0.6 & - & - & - & 14.4 & 1.0 & 2.6 & - & - & 5.3 & 15.8 & - \\
\hline$\sum$ macroalgal FA markers & 4.1 & 1.8 & 0.7 & 0.9 & 14.4 & 2.0 & 2.6 & 0.9 & 0.7 & 10.1 & 16.7 & 2.0 \\
\hline$\sum$ LCFAS & - & - & - & - & - & - & - & - & - & - & - & - \\
\hline$\Sigma$ PUFAs & 6.9 & 6.2 & 1.2 & 6.5 & 34.4 & 13.4 & 8.1 & 3.7 & 2.3 & 16.6 & 35.2 & 11.3 \\
\hline$C: N$ & 83.2 & 5.1 & 41.0 & 4.7 & 66.2 & 5.1 & 41.5 & 5.5 & 52.0 & 5.3 & 58.5 & 5.2 \\
\hline
\end{tabular}

The acid marker for diatoms was detected in all macrozoobenthos studied in Oura Bay during the rainy season (Table 5). In summer (dry season), 20:5 03 was found in Uca lactea and Cerithidiopsilla cingulata but not in Terebralia sulcata (Table 5). At Itoman flat, the diatoms marker was recorded in the 3 species only during the dry season (Table 6).

The fatty acids $18: 2 \omega 6$ and 18:3 $\omega 6$ were detected in all species at both sites and seaśons (Tables 5 \& 6). However, concentrations were relatively higher in the gastropods Terebralia sulcata in the rainy season

Table 5. Percentage level of 16:0, FA markers of bacteria, microalgae, macroalgae and mangroves (LCFAs), and total PUFAs in the main species of macrozoobenthos of Oura Bay during the rainy season (RS) and the dry season (DS). -: not detected

\begin{tabular}{|c|c|c|c|c|c|c|}
\hline \multirow[t]{2}{*}{ - } & \multicolumn{2}{|c|}{$\begin{array}{c}\text { Uca } \\
\text { lactea }\end{array}$} & \multicolumn{2}{|c|}{$\begin{array}{l}\text { Cerithideopsilla } \\
\text { cingulata }\end{array}$} & \multicolumn{2}{|c|}{$\begin{array}{l}\text { Terebralia } \\
\text { sulcata }\end{array}$} \\
\hline & RS & DS & RS & DS & RS & DS \\
\hline $16: 0$ & 32.6 & 44.8 & 25.2 & 18.3 & 20.2 & 30.1 \\
\hline $15: 0$ iso & 0.7 & 0.5 & - & - & - & - \\
\hline $15: 0$ anteiso & - & - & - & - & - & - \\
\hline $17: 0$ iso & 0.6 & 1.1 & 2.0 & 1.4 & 1.7 & 2.3 \\
\hline $17: 0$ anteiso & 0.5 & 0.6 & 0.8 & - & 0.6 & 0.5 \\
\hline $18: 1 \omega 7$ & 5.1 & 2.2 & 3.6 & 3.6 & 9.0 & 4.3 \\
\hline$\Sigma$ bacterial FA markers & 6.9 & 4.4 & 6.4 & 4.9 & 11.4 & 7.1 \\
\hline 20:5 $\omega 3$ (microalgal marker) & 4.1 & 1.3 & 0.9 & 2.6 & 1.9 & - \\
\hline $18: 2 \omega 6$ & 2.6 & 0.5 & 3.2 & - & 6.6 & 3.6 \\
\hline $18: 3 \omega 6$ & 1.1 & - & 1.2 & 0.8 & 4.3 & 1.2 \\
\hline$\sum$ macroalgal FA markers & 3.7 & 0.5 & 4.4 & 0.8 & 10.9 & 4.9 \\
\hline $26: 0$ & 1.2 & 0.7 & - & 0.8 & - & 3.8 \\
\hline $28: 0$ & - & 1.6 & 1.1 & 0.9 & 0.8 & - \\
\hline$\Sigma$ LCFAs & 1.1 & 2.2 & 1.1 & 1.7 & 0.8 & 3.8 \\
\hline$\sum$ PUFAs & 9.0 & 1.6 & 11.9 & 4.7 & 18.5 & 9.9 \\
\hline
\end{tabular}

$(10.8 \%)$ and Batillaria zonalis in the dry season $(12.6 \%)$.

The LCFAs were found in all species studied at Oura Bay during both seasons (Table 5). Their contributions were slightly higher during the dry season ( 1.7 to $3.8 \%)$ than in the rainy season (0.8 to $1.2 \%$ ). At Itoman flat, in both seasons, these fatty acid markers of the vascular plants were not detected in the macrozoobenthos collected (Table 6).

\section{DISCUSSION}

\section{Mangrove exportation}

The presence of LCFAs in the surface sediments along the Oura Bay intertidal flat during the rainy and the dry seasons indicates that decomposed leaves, and certainly other compounds from the mangrove forest, contributed to the intertidal pool of organic matter (Table 3). However, because of the relatively low percentages of LCFAs during summer and the absence of these markers at some stations (Stns OB 3 and $O B$ 5) during this season, it seems that exportation was less important than during the wet season, when the markers were detected at all stations (Table 3 ). This was confirmed by the elevated values of $\mathrm{C}: \mathrm{N}$ ratios, especially in the middle and lower parts of the flat (Table 3 ). 
Table 6. Percentage level of 16:0, FA markers of bacteria, microalgae, macroalgae and mangroves (LCFAs), and total PUFAs in the main species of macrozoobenthos of Itoman intertidal flat during the rainy season (RS) and the dry season (DS). -: not detected

\begin{tabular}{|c|c|c|c|c|c|c|}
\hline & \multicolumn{2}{|c|}{$\begin{array}{c}\text { Uca } \\
\text { lactea }\end{array}$} & \multicolumn{2}{|c|}{$\begin{array}{c}\text { Uca } \\
\text { vocans }\end{array}$} & \multicolumn{2}{|c|}{$\begin{array}{c}\text { Batillaria } \\
\text { zonalis }\end{array}$} \\
\hline & RS & DS & RS & DS & $\mathrm{RS}$ & DS \\
\hline $16: 0$ & 38.5 & 40.7 & 42.8 & 36.4 & 18.4 & 14.3 \\
\hline $15: 0$ iso & 0.6 & 0.7 & 0.5 & 0.6 & - & - \\
\hline 15:0 anteiso & - & 0.6 & - & - & - & - \\
\hline $17: 0$ iso & 0.9 & 1.3 & 1.0 & 0.7 & 1.7 & 1.1 \\
\hline $17: 0$ anteiso & 0.6 & 0.5 & 0.5 & 0.5 & - & 0.8 \\
\hline $18: 1 \omega 7$ & 2.4 & 2.3 & 4.2 & 2.4 & 3.6 & 2.7 \\
\hline$\Sigma$ bacterial FA markers & 4.4 & 5.4 & 6.2 & 4.2 & 5.3 & 4.6 \\
\hline $20: 5 \omega 3$ (microalgal marker) & - & 1.1 & - & 2.2 & - & 2.0 \\
\hline $18: 2 \omega 6$ & 1.7 & - & 1.6 & 2.8 & 5.9 & 6.4 \\
\hline $18: 3 \omega 6$ & - & - & - & 1.0 & 2.5 & 6.1 \\
\hline$\sum$ macroalgal FA markers & 1.7 & - & 1.6 & 3.8 & 8.4 & 12.6 \\
\hline$\sum$ LCFAs & - & - & - & - & - & - \\
\hline$\sum$ PUFAs & 3.4 & 1.7 & 2.9 & 6.2 & 18.0 & 25.8 \\
\hline
\end{tabular}

\section{Contribution of autochthonous sources}

In regard to the contributions of the bacterial fatty acid markers of surface sediments, these microorganisms constitute one of the main compounds of the organic matter pool at Oura Bay in both seasons (Fig. 2). However, the contribution of bacteria seemed to be elevated during the dry season, when the percentages of markers at some stations reached or exceeded $10 \%$ of the total fatty acids. In other respects, the higher contribution of bacteria during summer was confirmed by the low $\mathrm{C}: \mathrm{N}$ ratio values at some stations (Stns OB 3, OB 4 and OB5; see Table 3). Wafar et al. (1997) found high bacterial biomass in a mangrove-intertidal flat ecosystem at the MandoviZuari Estuary (India). They concluded In a comparable ecosystem, Boto \& Bunt (1981) assumed that such high $\mathrm{C}: \mathrm{N}$ ratio values in intertidal sediments were related to mangrove export. The relatively high export during the rainy season from the forest to the flat was certainly the result of intensive rainfall which drew the organic matter from the mangrove to the subtidal zone. Similarly, Hemminga et al. (1994) reported that mangrove production in Gazi Bay (Kenya) was exported in the direction of the ocean; however, this export decreased rapidly and had a marginal influence at a distance of $2 \mathrm{~km}$ offshore. In Oura Bay, the relative contribution of LCFAs in total fatty acids decreased from the mangrove shore to the subtidal zone (approximately $1 \mathrm{~km}$ ) in both seasons. This decrease indicates that the export of organic matter from mangroves was limited spatially to the intertidal zone.

At Itoman flat, despite the presence of drainage channels that carry particles and nutrients from the adjacent sugar cane plantation (vascular plants), LCFAs were not found in the surface sediments of the intertidal flat (Table 4). During the 2 seasons studied, the absence of sugar cane leaves or fragments during collections made in winter (from January to March) on the adjacent intertidal flat may explain the non-detection of LCFAs in the surface sediments. that this high biomass could only be maintained by mangrove forest export. However, at Oura Bay the

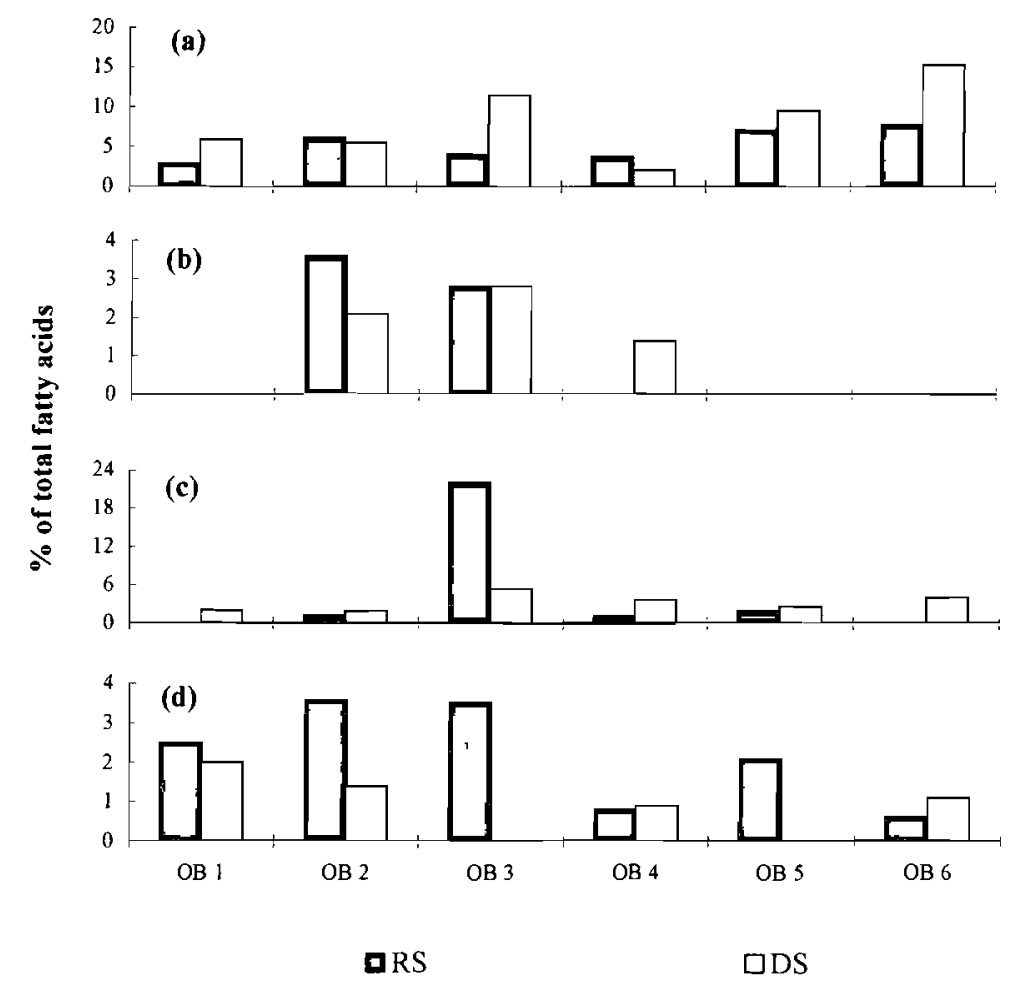

Fig. 2. Relative contributions of the food sources (a) bacteria, (b) diatoms, (c) green macroalgae and (d) mangroves in surface sediments at Stns OB1 to OB6 at Oura Bay during the rainy season (RS) and the dry season (DS) according to the sum of their respective markers: bacteria (15:0iso $+15: 0$ anteiso $+17: 0$ iso $+17: 0$ anteiso $+18: 1 \omega 7$ ), diatoms $(20: 5 \omega 3)$, green macroalgae $(18: 2 \omega 6+18: 3 \omega 6)$ and mangrove $(26: 0+28: 0+30: 0)$ 
contribution of bacteria in the organic matter pool was higher when export of detritus from the mangrove was reduced (dry season), indicating that other factors likely control the biomass of bacteria in the surface sediments (e.g., temperature, nitrogen supply, etc.). Despite this probable decrease of mangrove export, available detritus derived from mangroves certainly played an essential role in maintaining the high bacterial biomass during this season. Similarly, Bano et al. (1997) concluded that detritus was the main provider of energy, channelling nitrogen into the bacterial biomass in the Indus River delta (Pakistan). At Itoman flat, bacterial fatty acid markers reached or exceeded $10 \%$ of the total fatty acids at most of the stations during both seasons (Table 4). This shows the important contribution of bacteria to the organic matter of the surface sediments (Fig. 3).

Contributions of $20: 5 \omega 3$ in the intertidal surface sediments of Oura Bay indicate that diatoms seem to be poorly represented and restricted to some stations (Fig. 2). The presence of microphytobenthos may have induced the low $\mathrm{C}: \mathrm{N}$ ratios (Bano et al. 1997). During summer, benthic diatoms influenced the quality of the organic matter pool, because $20: 5 \omega 3$ was detected only at stations which presented relative low $\mathrm{C}: \mathrm{N}$ ratio values (Table 3 ) compared with other stations of the site. At the Itoman intertidal flat, with the exception of 1 station, benthic diatoms were absent during the wet season in regard to the contribution of 20:5 03 (Fig. 3). In summer this fatty acid was recorded at all stations, which may suggest a greater contribution of these microorganisms to the pool of organic matter (Fig. 3). This contribution of diatoms was confirmed by low C:N ratios (Table 4).

During the rainy season, the elevated contribution of

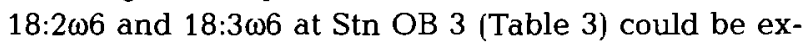
plained by the abundance of Enteromorpha intestinalis on and around this station (pers. obs.). Valiela (1984) indicates that the C:N ratio values of the green macroalgae were between 10 and 60 . Therefore, the $\mathrm{C}: \mathrm{N}$ ratio values from Stn OB 3 indicate an effective contribution of the green macroalgae to the organic matter. During summer, the macroalgal biomass increased (pers. obs.), which explains the larger distribution and greater contribution of green macrolagae in the surface sediment compared with the wet season (Fig. 2). At the Itoman intertidal flat, the contribution of green macroalgae to the pool of organic matter in the surface sediments during both seasons (Fig. 3) was not surprising due to the presence of Enteromorpha intestinalis and Ulva pertusa at this site. However, the biomass of macroalgae never equaled that observed when blooms occurred before (a)

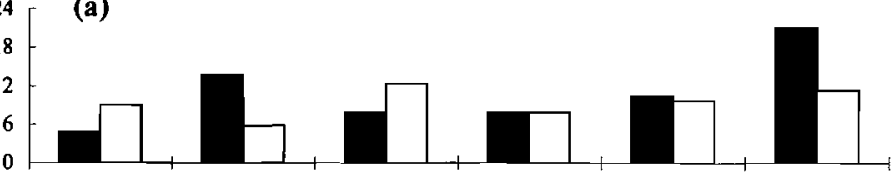

(b)
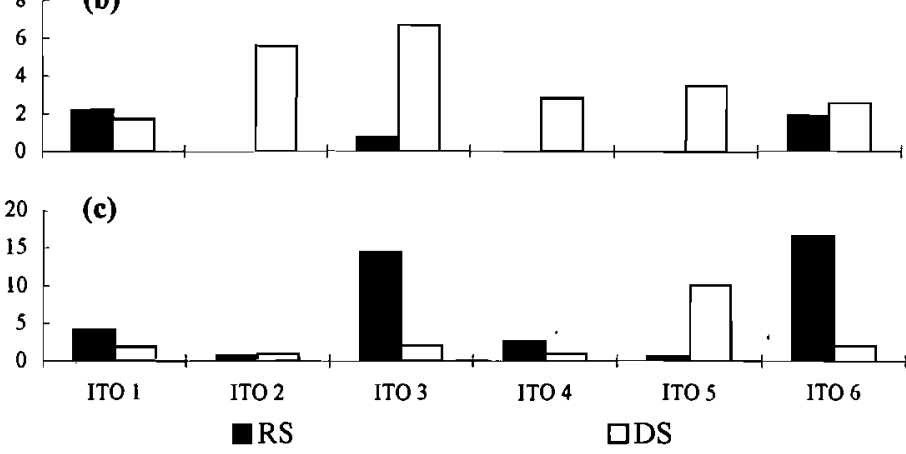

Fig. 3. Relative contributions of the food sources (a) bacteria, (b) diatoms and (c) green macroalgae, in surface sediments at Stns ITO 1 to ГTO 6 at $n$ intertidal flat during the rainy season (RS) and the dry season (DS) according to the sum of their respective markers

the rainy season. During the rainy season, the C:N ratios at Itoman intertidal flat (Table 4) were similar to those of the green macroalgae according to Valiela (1984). This may indicate that macroalgae were major contributors to the organic matter pool.

\section{Food sources of the macrozoobenthic species}

Independent of site and season, the sum of bacterial fatty acid contributions in the crabs Uca lactea and $U$. vocans suggests that microheterotrophs were the dominant food source (Figs. 4 \& 5). These results are in agreement with those obtained in a Queensland mudbank (Australia) by Dye \& Lasiak (1986), who showed that microheterotrophs were the major food source for 2 crabs of the Uca genus. However, Marguillier et al. (1997) concluded that $U$. lactea fed mostly on a mixture of seagrass and mangrove detritus in Gazi Bay. In Oura Bay this crab also ingested mangrove detritus as shown by the detection of LCFAs in its tissues (Table 5). However, the amounts of these fatty acids indicate a weak contribution of this food source to the diet of U. lactea (Fig. 4). At the Itoman intertidal flat, during both seasons, LCFAs were not detected in the tissues of $U$. lactea and $U$. vocans (Table 6 ). This was expected since there was an absence of high plant markers in surface sediments where the crabs were collected (Table 4). In other respects, according to the presence of 20:5 03 and the PUFAs markers, diatoms (benthic as well as planktonic) and macroalgae were also ingested by U. lactea and $U$. vocans (Fig. 5). However, those sources were less ingested compared to the bacteria. 


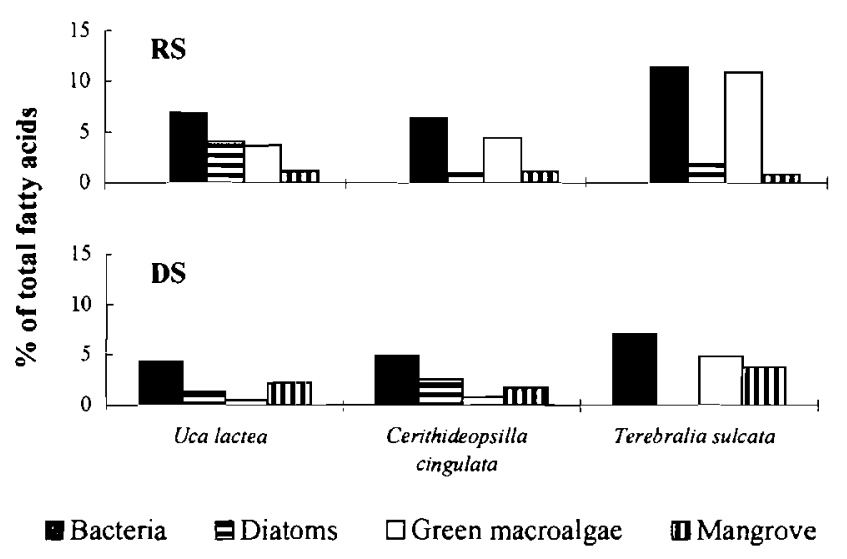

Fig. 4. Relative contributions of food sources in the macrozoobenthic species collected at Oura Bay during the rainy season (RS) and the dry season (DS) according to the sum of their respective markers

At Oura Bay, the elevated contribution of bacterial and PUFAs markers in the tissues of Terebralia sulcata during the rainy season indicated that the microheterotrophs and the macroalgae constitute the preferred food sources of this snail (Fig. 4). This diet pattern of $T$. sulcata was similar during the dry season, with a dominance of bacteria and macroalgae in the food diet (Fig. 4). Nevertheless, the relative high contribution of bacterial markers could also be explained by the presence of endobacteria, as observed for 2 species of snails (Pranal et al. 1996). This gastropod was mainly distributed in the interface between the mangrove forest and the upper flat (Motonaga 1977), which offered better availability of the mangrove leaf litter. However, these leaves contribute to the diet only in very small amounts with regard to LCFA percentages in $T$. sulcata. It is not known to what extent this material was used by this snail, but Slim et al. (1997) highlighted the dominant role of the snail $T$. palustris in removing leaf litter in the Gazi Bay mangrove forest. The results from Oura Bay may indicate the possibility that $T$. sulcata ingested the organic matter derived from the mangrove litter to assimilate the attached bacteria (rich in nitrogen) rather than to use the leaves themselves. Since Tenore's works $(1977,1981,1983)$ the role of the detritus derived from vascular plants has been well known as a 'support' of bacterial biomass for deposit-feeders. In other respects, the percentage of the $20: 5 \omega 3$ indicate that benthic and/or plankonic diatoms contributed weakly to the diet of this gastropod, and only in the wet season (Fig. 4).

According to the percentage of the bacterial markers, microheterotrophs were the main food source for the gastropod Cerithideopsilla cingulata in both seasons (Fig. 4). The contributions of $16: 2 \omega 6$ and $16: 3 \omega 6$ showed that green macroalgae were more ingested in the wet season than during summer (Fig. 4). The low

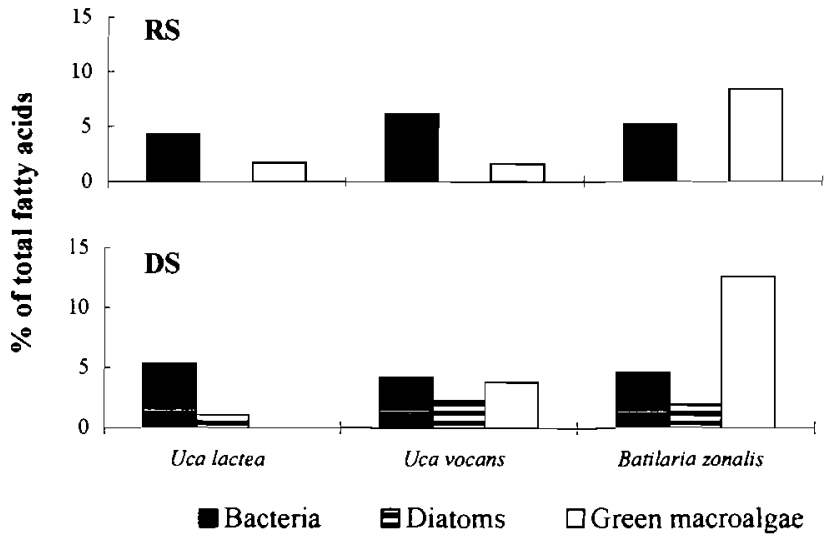

Fig. 5. Relative contributions of food sources in the macrozoobenthic species collected at Itoman during the rainy season (RS) and the dry season (DS) according to the sum of their respective markers

contribution of these acids markers in C. cingulata during the dry season could be linked to the decrease of these markers on the surface sediments at Stn OB 3, the site where the individuals were collected (Fig. 2).

At the Itoman intertidal flat, the contributions of $18: 2 \omega 6$ and $18: 3 \omega 6$ in the tissues of Batillaria zonalis indicated that the most important food source for this snail was green macroalgae (Fig. 5). Indeed, this was expected, as the individuals of this gastropod were always located on a macroalgal mat when they were collected (Stn ITO 3). The contributions of bacterial fatty acid markers suggest that bacteria were also ingested, but less than macroalgae (Fig. 5). However, for a gastropod of the same genus, Battilaria attramentaria, in a Californian salt marsh, diatoms were the most important food source (Whitlatch \& Obrenski 1980). Diatoms contributed to the diet of $B$. zonalis but in small amounts and only during the dry season according to the contribution of 20:5 103 . The summer detection of this acid in this species, as a well as in $U_{C a}$ lactea and $U$. vocans, is connected to the fact that the microphytobenthic biomass increased in the surface sediments compared to the wet season. The availability of diatom biomass may certainly induce a better use of these microorganisms by the macrozoobenthos.

In conclusion, a comparison of the percentages of LCFAs and the C: $N$ ratio of the 2 sites suggests that the organic matter derived from the mangrove forest was exported to the intertidal flat and that exportation was higher in the rainy season than in the dry season. The mangrove contributes to the diets of the intertidal macrozoobenthic species in Oura Bay. However, this contribution is weaker than those from other autochthonous food sources. Indeed, bacteria and macroalgae were the main food sources at this site as well as at the control site (Itoman intertidal flat). 
Acknowledgements. T.M. is grateful to the Japanese Society for the Promotion of Science (JSPS), which provided financial support for this work during his post-doctoral training. Thanks are given to $\mathrm{N}$. Toyama for help during sampling and $\mathrm{C}: \mathrm{N}$ analysis, Dr $\mathrm{H}$. Oku and $\mathrm{K}$. Onaga for assistance on improving the TLC technique, and Dr R. van Woesik and anonymous referees for critical reading of an earlier version of the manuscipt.

\section{LITERATURE CITED}

Alongi DM, Christoffersen P (1992) Benthic infauna and organism-sediment relations in a shallow, tropical coastal area: influence of outwelled mangrove detritus and physical disturbance. Mar Ecol Prog Ser 81:229-245

Bano N, Nisa M, Khan N, Saleem M, Harrison PJ, Ahmed Sl, Azam F (1997) Significance of bacteria in the flux of organic matter in the tidal creeks of the mangrove ecosystem of the Indus River delta, Pakistan. Mar Ecol Prog Ser 157:1-12

Bligh EG, Dyer WJ (1959) A rapid method of total lipid extraction and purification. Can J Biochem Physiol 37:911-917

Boto KG, Bunt JS (1981) Tidal export of particulate organic matter from a northern Australian mangrove system. Estuar Coast Shelf Sci 13:247-255

Canual EA, Cloern JE, Ringelberg DB, Guckert JB, Rau GH (1995) Molecular and isotopic tracers used to examine source of organic matter and its incorporation into the food webs on San Francisco Bay. Limnol Oceanogr 40:67-81

Currie BR, Johns RB (1988) Lipids as indicators of the origin of organic matter in fine marine particulate matter. Aust $\mathbf{J}$ Mar Freshw Res 39:371-383

Dye $\mathrm{AH}$, Lasiak TA (1986) Microbenthos, meiobenthos and fiddler crabs: trophic interactions in a tropical mangrove sediment. Mar Ecol Prog Ser 32:259-264

Fleming M, Guanghui L, Da Silveira Lobo Sternberg L (1990) Influence of mangrove detritus in an estuarine ecosystem. Bull Mar Sci 47(3):663-669

Hemminga MA, Slim FJ, Kazungu J, Ganssen GM, Nieuwenhuize J, Kruyt NM (1994) Carbon outwelling from a mangrove forest with adjacent seagrass beds and coral reefs (Gazi Bay, Kenya). Mar Ecol Prog Ser 106:201-301

Hopkins CCE, Sargent EM, Nilssen EM (1993) Total lipid content, and lipid and fatty acid composition of the deepwater prawn Pandalus borealis from Balsfjord, northern Norway: growth and feeding relationships. Mar Ecol Prog Ser 96:217-228

Jeffries PH (1972) Fatty acid ecology of tidal marsh. Limnol Oceanogr 17:433-440

Kharlemenko VI, Zhukova NV, Khotimchenko SV, Svetashev VI, Kamanev GM (1995) Fatty acids as markers of food sources in a shallow-water hydrothermal ecosystem (Kraternaya Bight, Yankich Island, Kurile lslands). Mar Ecol Prog Ser 120:231-241

LeBlanc CG, Bourbonnière RÄ, Schwarcz HP, Risk MJ (1989) Carbon isotopes and fatty acids analysis of the sediments of Negro Harbour, Nova Scotia, Canada. Estuar Coast Shelf Sci 28:261-276

Marguillier S, Van der Velde $G$, Dehairs $F$, Hemminga MA, Rajagopal S (1997) Trophic relationships in an interlinked mangrove-seagrass ecosystem traced by $\delta^{13} \mathrm{C}$ and $\delta^{15} \mathrm{~N}$. Mar Ecol Prog Ser 151:115-121

Meziane T, Bodineau L, Retiere C, Thoumelin G (1997) The use of lipid markers to define sources of organic matter in sediment and food web of the intertidal salt marsh-flat ecosystem of Mont-Saint-Michel Bay, France. J Sea Res 38:47-58

Mokolensang JG, Tokuyama A (1998) Litter production of mangrove forests at the Gesashi River. Bull Coll Sci Univ Ryukyus 65:73-79

Motonaga T (1977) Ecological distribution of macrobenthos in Oura mangrove swamp. Okinawa Master's Report, University of the Ryukyus

Mudge SM, Gwyn Lintern D (1999) Comparison of sterol biomarkers for sewage with other measures in Victoria Harbour, BC, Canada. Estuar Coast Shelf Sci 48:27-38

Pond DW, Bell MV, Harris RP, Sargent JR (1998) Microplanktonic polyunsaturated fatty acid markers: a mesocosm trial. Estuar Coast Shelf Sci 46 (A):61-67

Pranal V, Fiala-Médioni A, Guezennec J (1996) Fatty acids characteristics in two symbiotic gastropods from a deep hydrothermal vent of the West Pacific. Mar Ecol Prog Ser 142:175-184

Rajendran N, Matsuda O, Imamura N, Urushigawa Y.(1992) Determination of microbial biomass and its community structure from the distribution of phospholipid esterlinked fatty acids in sediments of Hiroshima Bay and its adjacent bays. Estuar Coast Shelf Sci 34:501-514

Rajendran N, Suwa Y, Urushigawa Y (1993) Distribution of phospholipid ester-linked fatty acids biomarkers for bacteria in the sediment of Ise Bay. Mar Chem 43:39-56

Robertson AI (1986) Leaf-burying crabs: their influence on energy flow and export from mixed mangrove forests (Rhizophora spp) in northeastern Australia. J Exp Mar Biol Ecol 102:237-248

Slim FJ, Hemminga MA, Ochieng C, Jannink NT, Cocheret de la Morinière E, van der Velde G (1997) Leaf litter removal by the snail Terebralia palustis (Linnaeus) and sesarmid crabs in an East African mangrove forest (Gazi Bay, Kenya). J Exp Mar Biol Ecol 215:35-48

Tam NFY, Vrijmoed LLP, Wong YS (1990) Nutrient dynamics associated with leaf decomposition in a small subtropical mangrove community in Hong Kong. Bull Mar Sci 47(1): $68-78$

Tenore KR (1977) Growth of Capitella capitata cultured on a various levels of detritus derived from different sources. Limnol Oceanogr 22:936-941

Tenore KR (1981) Organic nitrogen and caloric content of detritus. I. Utilization by the deposit-feeding polychaete Capitella capitata. Estuar Coast Shelf Sci 12:39-47

Tenore KR (1983) Organic nitrogen and caloric content of detritus. III. Effects on growth of a deposit-feeding polychaete Capitella capitata. Estuar Coast Shelf Sci 17: $733-742$

Valiela I (1984) Marine ecological processes. Springer Verlag, New York

Volkman JK, Johns RB, Gillian FT, Perry GI (1980) Microbial lipids of an intertidal sediment. I. Fatty acids and hydrocarbons. Geochim Cosmochim Acta 44:1133-1143

Wafar S, Untawale AG, Wafar M (1997) Litter fall and energy flux in a mangrove ecosystem. Estuar Coast Shelf Sci 44: $111-124$

Whitlatch RB, Obrebski S (1980) Feeding selectivity and coexistence in two deposit feeding gastropods. Mar Biol 58:219-225

Woodroffe CD (1985) Studies on a mangrove bassin, Tuff Crater, New Zealand. 1. Mangrove biomass and production of detritus. Estuar Coast Shelf Sci 20:265-280 